\title{
Rozvíjanie zručnosti počúvania s porozumením vo výučbe odborného nemeckého jazyka pre stredne pokročilých na Ekonomickej univerzite v Bratislave
}

\author{
Development of listening comprehension skills in teaching \\ German for intermediate students at the University of Economics \\ in Bratislava
}

\author{
Jana Kucharová, Ingrid Kunovská
}

\begin{abstract}
Abstrakt: Komunikatívna výučba cudzích jazykov si vyžaduje rozvíjat' u učiacich sa všetky jazykové zručnosti a kompetencie s cielom nadobudnút čo najvyššiu komunikatívnu kompetenciu v cielovom jazyku. Platí to i pre výučbu odborného jazyka. Na jednotlivých fakultách Ekonomickej univerzity v Bratislave absolvujú študenti dvoj- až trojsemestrálne kurzy odborného jazyka $v$ dvoch zvolených cudzích jazykoch. Nemecký jazyk je po angličtine druhým najpočetnejšie zastúpeným cudzím jazykom v rámci výučby na našej univerzite. Študenti si nemčinu vyberajú predovšetkým ako druhý cudzí jazyk. Úroveň jeho ovládania je preto nižšia, $\mathrm{v}$ rámci týchto kurzov dosahuje maximálne úroveň B1 podla Spoločného európskeho referenčného rámca pre jazyky. 0 to viac je potrebné ponúknut' študentom možnost' zlepšovat' ich komunikačné schopnosti pomocou rôznych metód, foriem i prostriedkov výučby a ukázat' im, ako sa jazykovej výučbe môžu venovat' aj samostatne, po absolvovaní kurzov odborného nemeckého jazyka v rámci ich vysokoškolského štúdia. Preto sme sa v rámci projektu KEGA (KEGA 005EU-4/2018) rozhodli zaoberat' problematikou rozvíjania receptívnej jazykovej zručnosti počúvania s porozumením v rámci výučby odborného nemeckého jazyka pre stredne pokročilých na jednotlivých fakultách Ekonomickej univerzity v Bratislave. Ako prostriedok na rozvíjanie počúvania s porozumením sme si na už existujúcej platforme vytvorili vlastný podcast. Použili sme ho ako médium, prostredníctvom ktorého sme postupne študentom zverejňovali nahrávky s textami na počúvanie s porozumením a rôzne typy úloh $\mathrm{k}$ nim. $\mathrm{V}$ príspevku prezentujeme čiastkové výsledky našej doterajšej práce a formulujeme východiská pre d’alšie, ešte hlbšie skúmanie zvolenej problematiky.
\end{abstract}

Klúčové slová: audionahrávky, autentickost', nové médiá, počúvanie s porozumením, podcast, úlohy

\begin{abstract}
Communicative foreign language learning requires learners to develop all language skills and competences in order to acquire the highest communicative competence in the target language. This also applies to the teaching of professional language. At the faculties of the University of Economics in Bratislava, students take two- to three-term courses of the professional language in two selected foreign languages. German is the second largest foreign language after English at our university. Students choose German primarily as a second foreign language. The level of proficiency is therefore lower, with a maximum B1 level according to the Common European Framework of Reference for Languages. All the more it is necessary to offer students the opportunity to improve their communication skills by means of various methods, forms and means of teaching and to show them how they can also pursue their own language
\end{abstract}


teaching after attending German language courses in their higher education. Therefore, within the KEGA project (KEGA 005EU-4/2018) we decided to address the issue of developing receptive language skills of listening comprehension in the framework of teaching German for intermediate students at various faculties of the University of Economics in Bratislava. As a means of developing listening comprehension, we have created our own podcast on an existing platform. We used it as a medium, through which we gradually published the recordings with texts for listening with comprehension and various types of tasks to them. In the paper we present partial results of our work so far and formulate the starting points for further, even deeper examination of the chosen issue.

Key words: audio recordings, authenticity, new media, listening comprehension, podcast, tasks

\section{1 Úvod}

Ciel’om nášho príspevku je prezentovat' doterajšie výsledky riešenia projektu KEGA (KEGA 005EU-4/2018), v rámci ktorého sa na Katedre nemeckého jazyka Fakulty aplikovaných jazykov Ekonomickej univerzity v Bratislave usilujeme napomáhat' študentom rozvíjat' receptívnu komunikačnú jazykovú zručnost' počúvanie s porozumením pomocou audionahrávok zverejňovaných na podcaste.

V prvej, teoretickej časti nášho príspevku, sa venujeme objasneniu niektorých klúčových pojmov, ktoré bezprostredne súvisia s problematikou rozvíjania komunikačnej jazykovej zručnosti počúvania s porozumením. Vzhl'adom na komplexnost' skúmanej problematiky a rozsah nášho príspevku sa zameriavame len na tri zo spomínaných klúčových pojmov, ktoré z hladiska zamerania nášho projektu na Ekonomickej univerzite v Bratislave zohrávajú v kontexte cudzojazyčnej výučby významnú úlohu. $\mathrm{V}$ úsilí podčiarknut' dôležitost' rozvíjania počúvania s porozumením s cielom nadobudnút' komunikatívnu kompetenciu študentov v reálnych komunikačných situáciách, sa v našom príspevku venujeme autentickosti ako jednému $\mathrm{z}$ dôležitých atribútov materiálov, $\mathrm{v}$ našom prípade textov, používaných v cudzojazyčnej výučbe. Ked’že náš projekt realizujeme pomocou podcastu, považujeme tiež za dôležité stručne poukázat' na výhody využívania nových médií vo výučbe cudzích jazykov a faktory, ktoré môžu ovplyvňovat' integráciu nových médií do výchovno-vzdelávacieho procesu. V závere teoretickej časti našej práce podávame krátku charakteristiku počúvania s porozumením ako komunikačnej jazykovej zručnosti, k rozvíjaniu ktorej sa realizáciou nášho projektu na Ekonomickej univerzite v Bratislave usilujeme prispiet'.

Tým plynule prechádzame k druhej, praktickej časti príspevku, v ktorej predstavujeme konkrétne kroky, ktoré sme $\mathrm{v}$ rámci riešenia projektu doteraz podnikli. Zameriavame sa predovšetkým na charakteristiku realizácie výskumu na Katedre nemeckého jazyka Fakulty aplikovaných jazykov Ekonomickej univerzity v Brati- 
slave a na prezentáciu čiastkových výsledkov, ktoré sme spracovali v priebehu doterajšej etapy výskumného procesu.

\subsection{Formulácia problému a jeho teoretický kontext}

Počúvanie s porozumením je jednou zo základných zručností ovládania cudzieho jazyka ako prvého aj ako druhého cudzieho jazyka. Jej nedostatočné ovládanie môže byt' jednou z hlavných príčin vzniku nedorozumení v rámci konverzácie v cudzom jazyku. Preto sme sa rozhodli venovat' jej zvýšenú pozornost' a v rámci výučby nemeckého jazyka ako druhého cudzieho jazyka na fakultách ekonomického zamerania Ekonomickej univerzity v Bratislave sme zatial' v období dvoch akademických rokov 2017/2018 a 2018/2019 uskutočnili ako súčast' projektu KEGA výskum zameraný práve na rozvíjanie zručnosti počúvania a následného spracovania počúvaných cudzojazyčných autentických textov.

Integráciu počúvania ako základnej jazykovej zručnosti do bežnej výučby cudzieho jazyka považujeme za vel'mi dôležitú súčast' vyučovacieho procesu. Jej nadobudnutie je náročný proces, ktorý si vyžaduje pozornost' ako zo strany vyučujúceho, tak aj zo strany študentov. Patrí k receptívnym komunikačným jazykovým zručnostiam. Jeho základnou funkciou nie je produkcia jazykových obsahov, ale práve ich vnímanie, prijímanie a spracovávanie. Ide o aktívnu činnost', prácu s cudzojazyčným obsahom, pri ktorej musí byt' študent schopný zrealizovat' súčasne viacero aktivít. Musí byt' schopný identifikovat' a rozlišovat' znenie počutého textu, rôzne zvuky, jednotlivým zvukovým jednotkám priradit’ správny význam a súčasne akceptovat' rôzne tempo, rytmus a melódiu reči, ako aj prípadné odchýlky, akcent, či dialekt počutého textu. Počutý obsah textu musí byt' dekódovaný, spracovaný a uložený, čo umožňuje správne pochopenie textu a jeho d’alšiu interpretáciu $\mathrm{v}$ rámci komunikačného procesu. Počúvanie s porozumením tak predstavuje základňu pre rozvoj d’alších produktívnych zručností, a to rozprávania a písania.

Počúvanie je definované ako multidimenzionálny konštrukt, ktorý pozostáva zo zložitých (a) afektívnych procesov, ako je motivácia k účasti na komunikácii; (b) behaviorálnych procesov, ako napríklad spätná väzba verbálnou a neverbálnou reakciou; (c) kognitívnych procesov, ako napríklad účast', porozumenie, prijímanie a interpretovanie obsahu a relačných správ (Halone et al., 1998).

Stradiotová et al. (2018, s. 141-156) upriamujú pozornost' na rozlišovanie nasledovných typov počúvania:

1. Rozlišujúce počúvanie - je inštrumentálny typ počúvania, ktorý je primárne fyziologický a vyskytuje sa väčšinou v prijímacej fáze procesu počúvania. V tejto fáze sa zaoberáme počúvaním a sledovaním okolia, aby sme izolovali určité sluchové alebo vizuálne podnety. Napríklad môžeme zamerat’ naše počúvanie na určitú čast' chodníka, dvora, etc., aby sme zistili, či nám nehrozí nebezpečen- 
stvo (Hargie, 2011, s. 185). Je to základná forma počúvania, ktorá je základom pre ostatné typy počúvania. Podla Wolvina a Coakleya (1993, s. 18-19) môže byt' tento typ počúvania zdokonalený. Hudobníci využívajú tento typ počúvania pri izolovaní špecifických zvukových stimulov.

2. Informačné počúvanie - cielom informačného počúvanie je porozumiet' a uchovávat' informácie. Tento typ počúvania nie je vyhodnocujúci a je bežný v kontexte výučby a učenia. Používame ho napríklad pri počúvaní správ, odkazov v mobilných telefónoch, informatívnych stretnutiach v práci, pri prijímaní pokynov, etc. Vzhladom na to, že zapamätanie a vybavenie si informácie sú dôležitými súčastami informačného počúvania, klúčové pre tento typ počúvania sú schopnost' sústredit' sa a dobré pamätové zručnosti.

3. Kritické počúvanie - cielom kritického počúvania je analyzovat' alebo vyhodnotit' správu na základe informácií, ktoré sú prezentované ústne a informácií, ktoré možno vyvodit' z kontextu. Kritický poslucháč vyhodnotí správu a prijme ju, odmietne ju alebo sa rozhodne, že informácie, ktoré dostal, nie sú preňho dostačujúce a vyhl’adá d’alšie informácie. Kritické počúvanie zvyčajne zahŕňa riešenie problémov a rozhodovanie.

4. Empatické počúvanie - tento typ počúvania je najnáročnejšou formou počúvania a stretávame sa s ním, ked’ sa pokúšame porozumiet' tomu, čo si hovoriaci myslí alebo čo cíti. Je to schopnost' vcítit' sa do jeho myslenia a pocitov. Empatické počúvanie je klúčom $\mathrm{k}$ dialógu a pomáha udržiavat' medzil’udské vztahy. Aby sa dosiahol dialóg, musia ludia disponovat' určitým stupňom otvorenosti a zdvorilosti, ktorá im umožňuje byt' empatickými a zároveň verit' a obhajovat' svoje vlastné postavenie. Ako príklad môžeme uviest' poradcov, terapeutov, etc., ktorí používajú empatické počúvanie, aby pochopili a nakoniec pomohli svojim klientom. Tento typ počúvania nezahŕňa rozhodovanie ani ponuku poradenstva, ale povzbudenie rečníka, aby vysvetlil a spracoval svoje pocity a emócie. Zručnosti, ako je objasnenie a reflexia, sa často používajú na to, aby sa zabránilo nedorozumeniam.

V kontexte výučby cudzích jazykov sa počúvanie s porozumením chápe ako zručnost' integrujúca komunikačné činnosti a stratégie, ktoré používatel'ovi cudzieho jazyka umožňujú porozumiet' hovorenému jazykovému prejavu. $\mathrm{V}$ rámci komunikačných jazykových zručností patrí spolu s čítaním s porozumením k tzv. receptívnym zručnostiam, pretože primárne má charakter prijímania hotového jazykového obsahu a práce s ním. Brinitzerová et al. (2013, s. 24-25) formulujú niekol'ko špecifických vlastností počúvania:

- to, čo počujeme, nemôžeme ovplyvnit',

- „prchavost“", pominutel'nost' počutého,

- bezprostrednost', priamost' počutého, recepcia je neovládatel'ný, neriadený proces, 
- paralelný priebeh viacerých kognitívnych procesov (dekódovanie, redukcia, ukladanie, predvídanie, tvorenie hypotéz a ich overovanie a verifikácia prípadne modifikácia),

- jazyk je spontánny, závisí od momentálnej situácie hovoriaceho, stavba viet je jednoduchá, počúvanie je sprevádzané zvukmi z prostredia, v ktorom prebieha.

V Spoločnom európskom referenčnom rámci (2006) pre jazyky je počúvanie alebo sluchová recepcia považovaná za súhrnný pojem receptívnych činností a stratégií, pri ktorých používatel' jazyka ako poslucháč prijíma a spracúva hovorený vstup pochádzajúci od jedného alebo viacerých hovoriacich. Autori SERR zarad'ujú k činnostiam počúvania:

- počúvanie verejných hlásení (informácie, pokyny, upozornenia, atd’),

- počúvanie médií (rozhlas, televízia, nahrávky, film),

- počúvanie v úlohe člena prítomného publika (divadlo, verejné schôdze, verejné prednášky, zábavné podujatia atd'),

- náhodne vypočuté rozhovory atd'.

Formulujú tiež dôvody, ktoré používatel’a jazyka vedú k tomu, aby počúval. Ide o tieto dôvody:

- porozumenie jadru veci,

- zachytenie špecifických informácií,

- detailné porozumenie všetkému,

- pochopenie naznačených súvislostí atd'. (SERR, 2006).

Samozrejme, všetky aspekty počúvania s porozumením je potrebné chápat’ s prihliadnutím na jazykovú úroveň konkrétnej učebnej skupiny.

Súčastou výučby cudzích jazykov je i práca s rôznymi typmi materiálov a podkladov s rôznorodým obsahom. Práca s nimi podporuje počas vyučovania, ale aj v rámci samostatného štúdia v domácom prostredí, význam autentickosti, preto je výber vhodných materiálov, textov a iných učebných zdrojov vel'mi dôležitý. Cielom výučby cudzích jazykov by malo byt' dosiahnut' prostredníctvom autentických obsahov a nových realite zodpovedajúcich úloh počas vyučovania skutočne autentickost' aj v interakcii a komunikácii, čo môžu vel'mi dobre podporit' aj moderné médiá. Autentické texty predstavujú prostriedok osvojenia si cudzieho jazyka, cudzej kultúry. Reprezentujú model kultúry cielového jazyka. Sú učebným materiálom, ktorý nie je umelo vytvorený pre špecifické metodické účely. Na rozdiel od didaktizovaných textov disponujú vlastnostou, ktorou je splnenie sociokultúrneho účelu v spoločenstve hovoriacich, z ktorého daný text aj pochádza. Ako uvádza Civegna (2005, s. 168-172), texty pochádzajú z jazykového spoločenstva, v ktorom 
je daný jazyk používaný ako materinský jazyk a kompletne odzrkadl'ujú vzt'ahy medzi pôvodnými tvorcami textu a ich prostredím.

Existuje niekol'ko definícií a charakteristík pre stupeň autentickosti cudzojazyčného textu. Niektoré tvrdia, že text možno považovat' za autentický alebo autenticky pôsobiaci vtedy, ked' nie je napísaný pre vyučovanie, ale pre „skutočný život“, za účelom uskutočnenia reálnej komunikácie.

Výhod začlenenia autentických textov $\mathrm{v}$ rôznych formách do výučby cudzích jazykov je niekol'ko. $V$ rámci nášho projektu, ktorý realizujeme na fakultách Ekonomickej univerzity v Bratislave, sa venujeme predovšetkým textom v podobe autentických audionahrávok, ktoré sme začlenili do výučby nemeckého jazyka ako druhého cudzieho jazyka. $V$ prvom rade by sme chceli zdôraznit' pozitívny vplyv takýchto textov na motiváciu študentov, ktorí prostredníctvom autentických textov prichádzajú do intenzívnejšieho kontaktu s cudzím jazykom, s jeho špecifikami. Študenti sú tak v priamom kontakte so „skutočným“ jazykom, ktorý nemusí byt' vždy očistený od nespisovných výrazov či slangu. Autentické texty sú taktiež zdrojom autentických kultúrnych a krajinovedných informácií o danej cudzojazyčnej oblasti. Vhodným výberom a prácou $\mathrm{s}$ autentickými materiálmi v rámci vyučovacieho procesu sa podporuje kreatívny prístup v procese výučby. Pritom je však vel'mi dôležité, aby vyučujúci upriamili svoju pozornost' na potreby skupiny a jednotlivcov. Ich potreby a úroveň ovládania cudzieho jazyka musia byt' v tomto procese akceptované a zohl'adňované. $\mathrm{V}$ inom prípade hrozí, že stanovené ciele sa vo vzdelávacom procese nedosiahnu.

V tejto súvislosti by sme ešte chceli poukázat' na význam autentickosti vo výučbe cudzích jazykov pri nadobúdaní a d’alšom rozvoji pragmatickej kompetencie, pod ktorou rozumieme schopnost' jednotlivca vytvorit’ v rámci komunikácie vzt’ahy, súvislosti medzi jazykovými formami, kontextom, situáciou, ako aj medzi osobami, ktoré sa komunikácie zúčastňujú.

Zaradenie nových médií do vyučovania cudzích jazykov si vyžaduje premyslenie pôvodnej formy vyučovania a učenia sa a uvedomenie si toho, akú pridanú hodnotu takáto forma výučby proti tradičnej predstavuje a aká sa zo strany vyučujúcich aj študentov očakáva. Integráciou textov, videí, animácií aj audiotextov v cudzom jazyku sa stáva vyučovací proces zaujímavejším, motivujúcejším. Ich obsahy sú prezentované názornejšie ako v tradičných médiách. Ďalšou z výhod práce s novými médiami v rámci výučby je objektívnost'. Spočíva v tom, že všetci študenti majú rovnaké podmienky pre ich aktivity, pre vypracovávanie zadaných úloh, rušivé momenty a efekty sympatií a antipatií medzi študentom a vyučujúcim sú prakticky nemožné. Svoje špecifiká má aj kombinovaná forma výučby, ktorá pozostáva z tradičnej formy vyučovacej hodiny, ktorá je doplnená modernými médiami. Vtedy je možné zmysluplne realizovat' kooperatívnu výučbu s individuálnym štúdiom v prostredí školy alebo doma. 
Efektívne zaradenie nových metód a médií do výučby cudzieho jazyka je vždy závislé od viacerých faktorov. Sú nimi študijná skupina, úroveň ovládania daného cudzieho jazyka v danej skupine, školská a vyučovacia situácia, stanovenie ciela, ktorý má byt' dosiahnutý, učebné obsahy, ako aj učebné predpoklady a potreby študentov. Len samotné zaradenie nových médií do výučby však nie je zárukou dosiahnutia očakávaného efektu. Ich didaktická pridaná hodnota sa dá dosiahnut' len ich dobre premyslenou integráciou $\mathrm{v}$ realizovanom didaktickom koncepte výučby.

\section{Metodológia výskumu na Ekonomickej univerzite v Bratislave}

Rozvíjaniu receptívnej komunikačnej jazykovej zručnosti počúvanie s porozumením venujeme na Ekonomickej univerzite osobitnú pozornost' predovšetkým v rámci projektu KEGA (KEGA 005EU-4/2018), ktorý riešime v období kalendárnych rokov 2018 až 2020. Hlavným cielom projektu je skúmanie vplyvu používania webovej aplikácie audioblog na rozvoj jazykových zručností počúvania s porozumením, hovorenia a na motiváciu študentov študovat cudzí jazyk vo zvýšenej miere a používat audioblog pri ich štúdiu. Cielom projektu je aj komparácia tradičnej formy výučby cudzích jazykov s výučbou podporovanou modernými technológiami, $\mathrm{v}$ tomto prípade $\mathrm{s}$ výučbou, $\mathrm{v}$ ktorej by sa využívala okrem tradičnej výučby v triede aj výučba podporovaná webovou aplikáciou audioblog. Výstupom projektu bude vyhodnotenie dát výskumu a vytvorenie metodickej príručky (manuálu), ktorá by v budúcnosti slúžila učitelom ako metodický návod na používanie audioblogu vo výučbe cudzích jazykov. Projekt realizujeme v rámci výučby anglického a nemeckého jazyka ako cudzieho jazyka. Motiváciou pre zapojenie sa do vyššie uvedeného projektu je aj naše úsilie využit' vel'ký záujem mladej generácie o nové médiá, predovšetkým internet, na to, aby sa zlepšili $v$ ich cudzojazyčných zručnostiach, $\mathrm{v}$ našom prípade v počúvaní s porozumením. Predpokladáme, že ich neobmedzený prístup $\mathrm{k}$ internetu u nich podporí aj ich záujem $\mathrm{k}$ využívaniu tohto média v rámci osvojovania si nemeckého jazyka.

Kedže nemecký jazyk si, vzhladom na doteraz povinnú výučbu angličtiny od základnej školy, študenti vyberajú predovšetkým ako druhý cudzí jazyk, rozhodli sme sa náš výskum realizovat' v rámci učebných skupín Odborného nemeckého jazyka pre stredne pokročilých. Ide o trojsemestrálny kurz nemeckého jazyka ako druhého cudzieho jazyka, ktorý na Katedre nemeckého jazyka Fakulty aplikovaných jazykov Ekonomickej univerzity v Bratislave absolvujú študenti Obchodnej a Národohospodárskej fakulty. Spomínaný kurz je nastavený tak, že študenti by mali začínat' na jazykovej úrovni A2 podla Spoločného európskeho referenčného rámca pre jazyky a po troch semestroch by mali dosiahnut' úroveň B1+. Samotný výskum a prácu na rozvíjaní počúvania s porozumením realizujeme $\mathrm{v}$ druhom semestri tohto kurzu, teda v rámci predmetu Odborný nemecký jazyk pre stredne pokročilých 2 . Cielovou skupinou sú študenti druhého ročníka bakalárskeho 
stupňa vyššie spomínaných fakúlt Ekonomickej univerzity v Bratislave. V súlade $s$ cielom riešeného projektu KEGA prebieha náš výskum $v$ dvoch paralelných skupinách, z ktorých jedna je experimentálna a druhá kontrolná. Na vytváranie učebných skupín nemáme stanovené kritériá. Jednotlivé skupiny, ktoré sú pomerne heterogénne, tvoria študenti zapísaní na daný predmet. Heterogénnost' skupín je zapríčinená tým, že študenti na začiatku kurzu Odborného nemeckého jazyka pre stredne pokročilých neabsolvujú vstupné testy a počas troch semestrov kurzu nepracujú v pôvodných skupinách.

V rámci obidvoch výskumných skupín (experimentálnej aj kontrolnej) sa v druhom týždni semestra píše so študentami vstupný test zameraný na počúvanie s porozumením. Test pozostáva z ôsmich krátkych (pribl. minútových) nahrávok. Ku každej z nich musia študenti vyriešit' dve úlohy s výberom odpovede - výber z 2 alebo z 3 možností, pričom vždy je správna iba jedna ponúkaná možnost'. $\mathrm{K}$ vol'be uvedeného typu úloh nás viedla práve spomínaná heterogénnost' učebných skupín a aktuálna skutočnost', že úroveň ovládania nemeckého jazyka ako druhého cudzieho jazyka má v ostatnom období klesajúcu tendenciu. Úlohy vo vstupnom teste sú tematicky orientované predovšetkým na všeobecný jazyk (každodenné komunikačné témy) s postupným prechodom aj k odbornejším témam (pracovné prostredie, dohodnutie termínu).

Študenti experimentálnej skupiny následne od 2. do 11. týždňa semestra dostávajú týždenne jednu nahrávku s úlohami na podcast, ktorý sme si vytvorili na už existujúcej platforme https://hoerverstehen.podbean.com. Nahrávky ku všetkým zadávaným úlohám používame $\mathrm{z}$ verejne dostupných internetových zdrojov (predovšetkým z https://www.audio-lingua.eu/). Náročnost' zadávaných úloh sa postupne zvyšuje. Mení sa ich tematické zameranie aj typ. Kým vo vstupnom teste sme uprednostnili výlučne úlohy s výberom odpovede (zatvorené otázky), v rámci počúvaní počas jednotlivých týždňov semestra sú študenti konfrontovaní jednak $\mathrm{s}$ úlohami s výberom odpovede, jednak s úlohami na doplnenie odpovede (otvorené otázky). $\mathrm{Z}$ úloh s výberom odpovede využívame dichotomickú úlohu (richtig/falsch). Vzhladom na to, že pravdepodobnost' správnej odpovede pri tomto type úlohy je pomerne vysoká, využívame ju predovšetkým $\mathrm{v}$ rámci prvej polovice zadávaných úloh. $\mathrm{Z}$ úloh na doplnenie správnej odpovede využívame doplnenie slov, odpovede na otázky celou vetou a doplnenie chýbajúcich slov do krátkeho zhrnutia vypočutého textu. $\mathrm{V}$ úlohách, v ktorých mali študenti formulovat' celé vety - odpovede na otázky celou vetou - sme pri hodnotení zohladňovali obsahovú aj jazykovú stránku (hodnotili sme aj gramatické chyby).

$\mathrm{Z}$ vyššie spomenutých typov úloh, ktoré používame $\mathrm{v}$ rámci nášho výskumu, je zrejmé, že niektoré úlohy sú zamerané na globálne porozumenie textu (predovšetkým dichotomická úloha a úloha na dopíňanie slov do zhrnutia vypočutého textu), 
niektoré zasa na porozumenie niektorých špecifických informácií (selektívne počúvanie) alebo na porozumenie detailným informáciám (detailné počúvanie).

Témy jednotlivých textov sú, $\mathrm{v}$ súlade so sylabami daného kurzu a autentickým nemeckým učebným materiálom používaným v rámci jeho výučby, ktorého cielom je pripravit' študentov na ich uplatnenie sa na pracovnom trhu v nemecky hovoriacom jazykovom prostredí, zamerané na pracovné prostredie, organizáciu pracovného dňa, pracovnej cesty, telefonické rozhovory v práci atd'. Súčastou týchto textov zámerne nie je výlučne ekonomická terminológia, pretože cielom projektu, $\mathrm{v}$ rámci ktorého výskum realizujeme, je úsilie využitie jeho výstupov nielen na Ekonomickej univerzite v Bratislave, ale aj na iných univerzitách alebo odborných vysokých školách, ktorých absolventi sa po skončení štúdia chcú úspešne uplatnit' na pracovnom trhu v nemeckom jazykovom prostredí.

Na obrázku č. 1 možno vidiet' ukážku vyššie spomínanej platformy, ktorá nám slúžila na zverejňovanie jednotlivých nahrávok a $\mathrm{k}$ nim prislúchajúcich úloh pre študentov.

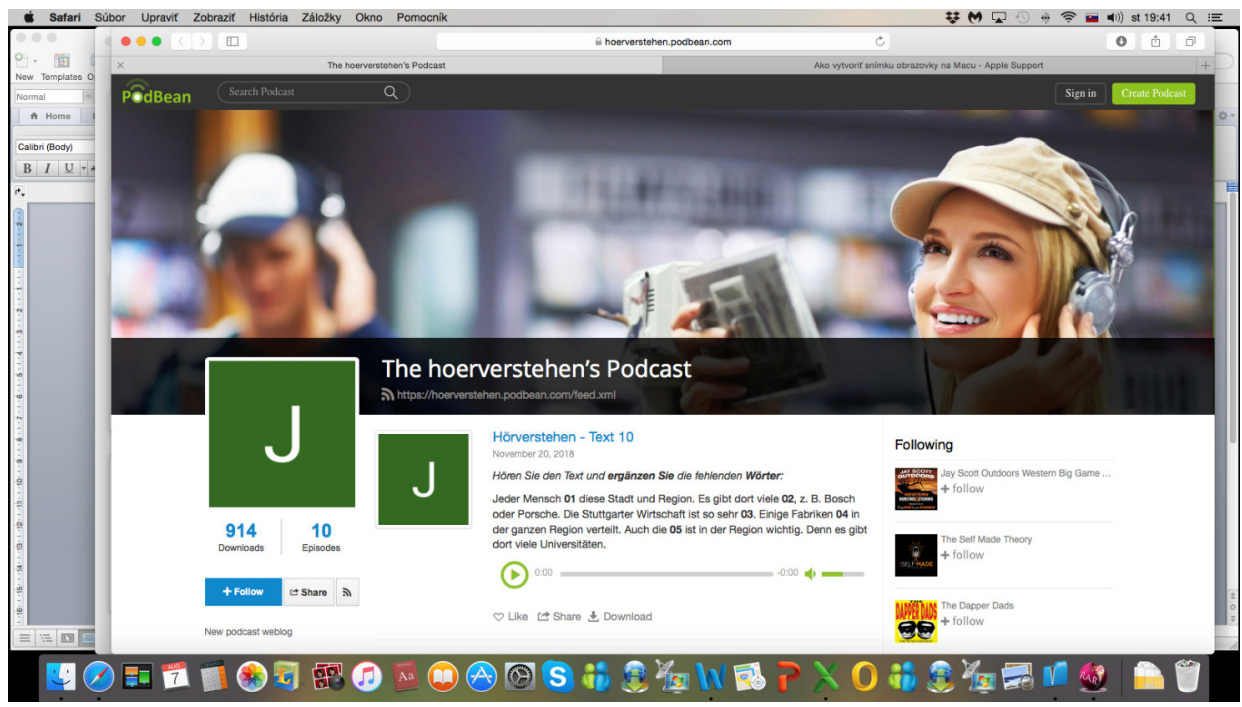

Obr. 1: Podcast slúžiaci na výskum rozvíjania počúvania s porozumením vo výučbe nemeckého jazyka ako druhého cudzieho jazyka

Pre výber tejto platformy sme sa rozhodli na základe dohody s kolegami realizujúcimi projekt v rámci výučby anglického jazyka. Platforma je verejne dostupná a rozsahovo dostačujúca pre naše potreby. Pri úlohách teda musíme dodržiavat' pomerne obmedzený rozsah, ktorý nám platforma ponúka, musia byt' formulované čo najstručnejšie, čo však v rámci nami preferovaných jazykových úrovní 
v žiadnom prípade nepovažujeme za nevýhodu. $\mathrm{V}$ rámci semestra teda študenti dostávajú postupne 10 nahrávok, ktoré $\mathrm{z}$ týždňa na týždeň musia vypracované priniest' na seminár alebo zaslat' elektronicky vyučujúcemu, ktorý následne vypracované úlohy zhodnotí a $\mathrm{v}$ rámci vyučovacích hodín študentov priebežne informuje o výsledkoch a upozorňuje ich na chyby, ktorých sa pri vypracovávaní jednotlivých úloh dopúštajú. Tým získavajú študenti spätnú väzbu s cielom vyhnút' sa daným chybám pri riešení d’alších úloh. Komunikácia medzi študentmi a vyučujúcimi teda neprebieha výlučne online, má kombinovanú formu, čím cielene podporujeme interakciu medzi vyučujúcimi a študentmi, nakol'ko zastávame názor, že zaradenie akýchkolvek, aj nových a moderných médií do vyučovacieho procesu nenahradí prítomnost' vyučujúceho, a to zvlášt', ak ide o výučbu cudzích jazykov vo forme seminára. V 12. týždni semestra píšu študenti experimentálnej a kontrolnej skupiny opät' test, tentokrát výstupný, ktorý nám slúži na overenie ich pokroku $\mathrm{v}$ počúvanní s porozumením. Výstupný test je obdobný vstupnému testu, obsahuje rovnaké typy úloh, s tým rozdielom, že ich náročnost' je vyššia. Študenti experimentálnej skupiny okrem toho vypíňajú dotazník, ktorým sa usilujeme zistit' aj splnenie d’alších čiastkových cielov projektu - napríklad komparácie motivácie študentov $\mathrm{k}$ štúdiu nemeckého jazyka či vplyvu používania webovej aplikácie na zverejňovanie nahrávok s úlohami atd'. Dotazník obsahuje 10 otázok zameraných na zistenie spätnej väzby od študentov v súvislosti s ich motiváciou k štúdiu jazyka, so spôsobom práce s platformou, s časom stráveným pri riešení úloh, s prístupom k internetu. Zaujíma nás aj názor študentov na vhodnost' výberu jednotlivých nahrávok.

\section{Doterajšie výsledky výskumu a diskusia}

Kedže náš výskum je stále $\mathrm{v}$ procese a nie je ukončený, prezentujeme $\mathrm{v}$ našom príspevku jeho doterajšie výsledky so zameraním na niektoré aspekty skúmanej problematiky. $\mathrm{V}$ tabul'ke č. 1 stručne uvádzame základné charakteristiky experimentálnej a kontrolnej skupiny v rámci doteraz vyhodnotenej etapy výskumu.

Tab. 1: Základné charakteristiky experimentálnej a kontrolnej skupiny

\begin{tabular}{|l|c|c|}
\hline Charakteristika & Experimentálna skupina & Kontrolná skupina \\
\hline Počet študentov: & 56 & 60 \\
\hline Muži: & 23 & 21 \\
\hline Ženy: & 33 & 39 \\
\hline Ročník štúdia: & druhý & druhý \\
\hline Stupeň štúdia: & prvý & prvý \\
\hline Fakulta EU v Bratislave: & OF, NHF & OF, NHF \\
\hline
\end{tabular}

Odchýlka v počte študentov $\mathrm{v}$ experimentálnej a kontrolnej skupine je daná rozdielnym počtom študentov $\mathrm{v}$ jednotlivých učebných skupinách $\mathrm{v}$ rámci predmetného kurzu. 
V tabul'kách 2 a 3 sú zhrnuté doterajšie, teda len čiastkové výsledky vstupného a výstupného testu v rámci experimentálnej a kontrolnej skupiny.

Tab. 2: Výsledky vstupného testu v rámci experimentálnej a kontrolnej skupiny

\begin{tabular}{|l|c|c|}
\hline $\begin{array}{l}\text { Vstupný test (maximálny možný } \\
\text { počet bodov 32) }\end{array}$ & Experimentálna skupina & Kontrolná skupina \\
\hline Dosiahnuté maximum v bodoch & 30 & 28 \\
\hline Dosiahnuté maximum v percentách & 94 & 88 \\
\hline Dosiahnuté minimum v bodoch & 12 & 8 \\
\hline Dosiahnuté minimum v percentách & 38 & 25 \\
\hline Priemer v bodoch & 20,07 & 20,07 \\
\hline Priemer v percentách & $\mathbf{6 2 , 8 8}$ & $\mathbf{6 2 , 8 8}$ \\
\hline
\end{tabular}

Je pozoruhodné, že experimentálna aj kontrolná skupina dosiahli vo vstupnom teste rovnaký priemerný počet bodov. Túto situáciu si vysvetlujeme práve spomínanou heterogénnostou skupín. Na základe tohto výsledku sa domnievame, že vstupné vedomosti študentov $\mathrm{v}$ obidvoch skupinách boli na približne rovnakej úrovni. Opätovne však zdôrazňujeme, že tento poznatok nie je konečný a predpokladáme, s pribúdajúcim počtom študentov v experimentálnej i kontrolnej skupine sa postupne bude menit'.

Tab. 3: Výsledky výstupného testu v rámci experimentálnej a kontrolnej skupiny

\begin{tabular}{|l|c|c|}
\hline $\begin{array}{l}\text { Vstupný test (maximálny možný } \\
\text { počet bodov 32) }\end{array}$ & Experimentálna skupina & Kontrolná skupina \\
\hline Dosiahnuté maximum v bodoch & 32 & 30 \\
\hline Dosiahnuté maximum v percentách & 100 & 94 \\
\hline Dosiahnuté minimum v bodoch & 12 & 0 \\
\hline Dosiahnuté minimum v percentách & 38 & 0 \\
\hline Priemer v bodoch & $\mathbf{2 2 , 5}$ & $\mathbf{2 1 , 9 7}$ \\
\hline Priemer v percentách & $\mathbf{7 0 , 4 6}$ & $\mathbf{6 8 , 7 8}$ \\
\hline
\end{tabular}

Ak si porovnáme obidve tabul'ky s výsledkami vstupných a výstupných testov experimentálnej a kontrolnej skupiny, vidíme, že, hoci nie markantne, ale predsa, výsledky v experimentálnej skupine naznačujú, že tréning počúvania s porozumením pomocou nahrávok zverejňovaných študentom na podcaste určite prispieva $\mathrm{k}$ postupnému rozvíjaniu tejto receptívnej komunikačnej jazykovej zručnosti. Treba povedat', že zatial' ide o čiastkové výsledky výskumu, pretože jeho realizácia bude pokračovat' aj v nastávajúcom akademickom roku. Znamená to, že sa značne zvýši výskumná vzorka v obidvoch skupinách. Do akej miery d’alšie etapy výskumu ovplyvnia jeho doterajšie výsledky, budeme prezentovat' v naších d’alších prácach a príspevkoch.

Na mieru rozvíjania komunikačnej jazykovej zručnosti počúvania s porozumením v experimentálnej skupine našej výskumnej vzorky majú určite vplyv aj samotné 
nahrávky a typy úloh, ktoré k nim študenti majú vypracovat'. Vel'kou výhodou zverejnenia nahrávok a úloh na podcaste je, že sú stále dostupné a študenti sa $\mathrm{k}$ nim môžu kedykolvek vrátit'. Nahrávku si môžu vypočut' neobmedzene velakrát, rovnako úlohy môžu v priebehu daného týždňa riešit' opakovane, kedykol'vek a kdekol'vek, kde majú prístup k internetu. Kedže podcast poskytuje aj prehlady jeho navštevovanosti, môžeme konštatovat', že študenti tieto neobmedzené možnosti pomerne málo využívajú. Práve v tejto súvislosti považujeme za dôležitý aj čiastkový ciel' projektu zameraný práve na motiváciu študentov $\mathrm{k}$ učeniu sa cudzích jazykov. Dotazníky, ktoré študenti v experimentálnych skupinách v tejto súvislosti vypíňali, sú $\mathrm{v}$ súčasnosti v štádiu vyhodnocovania a budú spracované po ukončení realizácie výskumu. Z priebežnej analýzy dotazníkov sa nám však potvrdzuje, že hoci študenti považujú nahrávky a úlohy za vhodnú a zaujímavú doplnkovú formu výučby, venujú im len vel'mi málo času (niekol'ko minút týždenne). $V$ tejto súvislosti by bolo podla nás určite vhodné zaoberat' sa aj touto skutočnost'ou a jej príčinami.

\section{Závery a podnety na d'alší výskum}

Cielom nášho príspevku bolo predstavit' jednu z možností rozvíjania receptívnej komunikačnej jazykovej zručnosti počúvania s porozumením $v$ rámci výučby nemeckého jazyka ako druhého cudzieho jazyka na fakultách Ekonomickej univerzity v Bratislave. V rámci projektu KEGA (KEGA 005EU-4/2018) s podčiarknutím autentickosti a dôležitosti využívania nových médií vo výučbe cudzích jazykov ponúkame študentom možnost' zlepšovat' svoju schopnost' počúvat' a spracovávat' počutý jazykový obsah pomocou nahrávok a úloh zverejňovaných na podcaste. Výsledky doterajšieho výskumu naznačujú, že aj táto forma môže byt' efektívnym doplnkom výučby cudzích jazykov na vysokej škole. Vyžaduje si však ešte komplexnejšie skúmanie, precíznejšie rozpracovanie a hlbšiu analýzu d'alších faktorov ovplyvňujúcich dosiahnuté výsledky študentov vo vstupných a výstupných testoch, ale aj v jednotlivých čiastkových úlohách. Ako vhodné podnety na hlbší výskum vnímame analýzu typov jednotlivých úloh vo vztahu k riešeniam študentov (ktoré typy im robili najväčšie problémy a prečo), analýzu typov úloh vzhladom na typ počúvania (či študentom robili viac problémy úlohy zamerané na globálne porozumenie textu alebo úlohy zamerané na porozumenie konkrétnych informácií). Rovnako, ako sme už uviedli vyššie, je potrebné analyzovat' spätnú väzbu od študentov (dotazníky) a kvalitatívne posúdit' ich odpovede týkajúce sa otázok vplyvu tohto spôsobu výučby na ich motiváciu k štúdiu cudzieho jazyka. Práve tieto aspekty zvolenej problematiky plánujeme rozpracovat' $\mathrm{v}$ druhej polovici riešenia projektu, t. j. v akademickom roku 2019/2020 a 2020/2021. 


\section{Literatúra}

Brinitzer, M. ET AL. (2013). DaF unterrichten. Basiswissen Didaktik Deutsch als Fremd- und Zweitsprache. Stuttgart: Ernst Klett Sprachen GmbH.

Civegna, K. (2005). Authentische Texte. In Krechel, H.-L. (2005). Mehrsprachiger Fachunterricht in Ländern Europas. Tübingen: Gunter Narr Verlag.

HARgie, O. (2011). Skilled Interpersonal Interaction: Research, Theory, and Practice. London: Routledge.

Spoločný európsky referenčný rámec pre jazyky. Učenie sa, vyučovanie, hodnotenie. (2017). Bratislava: Štátny pedagogický ústav. Dostupné z https://www.statpedu.sk/files/sk/publikacna-cinnost/ publikacie/serr_tlac-indd.pdf

STRADIOTOvÁ E. (2019). Rozvoj jazykových zručností prostredníctvom moderných technológií. In ŠTEFANČík, R. (2019). Aktuálne pohlady na výskum cudzích jazykov a interkultúrnej komunikácie. Zborník vedeckých prác. Trnava: Slovenská spoločnost' pre regionálnu politiku pri SAV.

STRADiotovÁ, E. ET AL. (2018). Počúvanie s porozumením s podporou technológií. In KunOvSKÁ, I. (2018). Moderné trendy vo výučbe cudzích jazykov. Brno: Tribun EU.

Wolvin, A. D., CoAkley, C. G. (1993). A Listening Taxonomy. In Wolvin, A. D., CoAKLey, C. G. (1993). Perspectives on Listening. Norwood, N. J.: Ablex Publishing Corporation.

Tento príspevok je čiastkovým výstupom riešenia grantového projektu KEGA č. 005EU-4/2018 Vplyv webovej aplikácie audioblog na rozvoj jazykových zručností počúvanie s porozumením a rozprávanie vo výučbe cudzích jazykov.

\section{Autorky}

Mgr. Jana Kucharová, PhD., Katedra nemeckého jazyka, Fakulta aplikovaných jazykov, Ekonomická univerzita v Bratislave, e-mail: jana.kucharova@euba.sk

Autorka pôsobí od roku 2014 ako odborná asistentka na Katedre nemeckého jazyka Fakulty aplikovaných jazykov Ekonomickej univerzity v Bratislave. Vyučuje Odborný nemecký jazyk pre stredne pokročilých, Odborný nemecký jazyk pre pokročilých a odborné predmety v nemeckom jazyku ako Reálie nemecky hovoriacich krajín a Slovenska, Kultúra a komunikácia a Rokovania v nemeckom jazyku. Vo svojej publikačnej a vedeckej činnosti sa zaoberá didaktikou a metodikou nemeckého jazyka ako cudzieho jazyka, učebnými stratégiami, vyučovacími metódami a tvorbou testov. Nadobudnuté vedomosti a skúsenosti z tejto oblasti uplatňuje aj v rámci projektovej činnosti a prezentuje ich na konferenciách a vo svojich publikačných výstupoch doma i v zahraničí.

Mgr. Ingrid Kunovská, PhD., Katedra nemeckého jazyka, Fakulta aplikovaných jazykov, Ekonomická univerzita v Bratislave, e-mail: ingrid.kunovska@euba.sk

Autorka pôsobí ako odborná asistentka na Katedre nemeckého jazyka Fakulty aplikovaných jazykov Ekonomickej univerzity v Bratislave od roku 2001. Na všetkých odborných fakultách univerzity vyučuje Odborný nemecký jazyk pre stredne pokročilých, Odborný nemecký jazyk pre pokročilých a Reálie nemecky hovoriacich krajín a Slovenska. Svoju publikačnú a vedeckú činnost' zameriava na didaktiku a metodiku nemeckého jazyka ako cudzieho jazyka, ako aj na učebné stratégie a vyučovacie metódy v rámci výučby cudzích jazykov. Získané vedomosti a skúsenosti z uvedených oblastí uplatňuje aj v rámci projektovej činnosti a prezentuje ich na konferenciách a vo svojich domácich aj zahraničných publikačných výstupoch. 